\title{
Valorization of Globe Artichoke (Cynara scolymus) Agro-Industrial Discards, Obtaining an Extract with a Selective Effect on Viability of Cancer Cell Lines
}

\author{
Diana Noriega-Rodríguez ${ }^{1}$, Carmen Soto-Maldonado ${ }^{2} \mathbb{}$, Cristian Torres-Alarcón ${ }^{3}$, \\ Lorenzo Pastrana-Castro ${ }^{4}$, Caroline Weinstein-Oppenheimer ${ }^{5}$ and \\ María Elvira Zúñiga-Hansen 2,3,* \\ 1 Departamento de Química Analítica y Alimentaria, Universidade de Vigo, Circunvalación ao Campus \\ Universitario, 36310 Vigo, Pontevedra, Spain; diana.noriega.rodriguez@gmail.com \\ 2 Centro Regional de Estudios en Alimentos Saludables, Av. Universidad 330, Curauma-Placilla, \\ Valparaíso 2373223, Chile; carmensoto@creas.cl \\ 3 Escuela de Ingeniería Bioquímica, Pontificia Universidad Católica de Valparaíso, Av. Brasil 2085, \\ Valparaíso 2362803, Chile; citorres86@gmail.com \\ 4 International Iberian Nanotechnology Laboratory, Av. Mestre José Veiga s/n, 4715-330 Braga, Portugal; \\ pastrana@uvigo.es \\ 5 Escuela de Química y Farmacia, Facultad de Farmacia, Universidad de Valparaíso, Av. Gran Bretaña 1093, \\ Valparaíso 2360102, Chile; caroline.weinstein@uv.cl \\ * Correspondence: maria.zuniga@pucv.cl
}

Received: 23 May 2020; Accepted: 16 June 2020; Published: 20 June 2020

check for updates

\begin{abstract}
Globe artichoke (Cynara scolymus L.) is considered one of the most significant sources of phenolic antioxidants in nature. However, more than $60 \%$ of its total volume is discarded for consumption purposes, making available an abundant, inexpensive and profitable source of natural antioxidants in the discarded fractions. Polyphenolic antioxidants from a South American variety of artichoke agro-industrial discards (external bracts and stems) were obtained by mild extraction processes. Best results were achieved at $40{ }^{\circ} \mathrm{C}, 75 \%$ of ethanol and $10 \mathrm{~min}$ of reaction, obtaining $2.16 \mathrm{~g}$ gallic acid equivalent (GAE)/100 g of total phenolic compounds (TPC) and 55,472.34 $\mu \mathrm{mol}$ Trolox equivalent (TE)/100 g of antioxidant capacity (oxygen radical absorbance capacity (ORAC)). High-performance liquid chromatography (HPLC) analyses determined that caffeoylquinic acids comprise up to $85 \%$ of the total polyphenolic content, and only around $5 \%$ are flavonoids. Inulin content in the artichokes residues was recovered (48.4\% dry weight $(\mathrm{dw}))$, resulting in an extract with $28 \%$ of inulin in addition to the aforementioned antioxidant capacity. The artichoke discard extract in a concentration of $500 \mathrm{mg} / \mathrm{L}$ produced a strong decrease in Caco-2 and MCF-7 cancer cell lines viability, whereas healthy fibroblasts maintained their viability when the extract was concentrated at $1500 \mathrm{mg} / \mathrm{L}$. These results suggest that the artichoke extract presents a good anti-proliferative potential effect on Caco-2 and MCF-7 cells.
\end{abstract}

Keywords: artichoke discards; polyphenols; antioxidant activity; inulin; Caco-2; MCF-7

\section{Introduction}

Globe artichoke (Cynara scolymus L.) is a herbaceous perennial plant belonging to the Asteraceae family. The artichoke is considered one of the vegetables with the highest antioxidant capacity and content of polyphenols and presents a significant content of fructooligosaccharides such as inulin. These kinds of compounds provide substantial health-promoting benefits. Artichokes are commercialized fresh, depending on the seasonality of producing countries, although most of the world production 
of this vegetable is destined to downstream processes, mainly as a canned food [1-3]. In this regard, only the heart and some inner bracts of the artichoke are traded as canned products, while $60-85 \%$ of the total processed dried matter of the vegetable is discarded [1,4-6]. This great volume of discards, comprising substantial amounts of valuable bioactive compounds, seems reasonable to be used as natural materials to make rational use of in a vast number of fields, particularly-and for the reasons mentioned above - as functional ingredients for the food and nutraceutical industries $[4,6,7]$.

In this aspect, different studies $[1,4,5,8,9]$ have shown the potential of polyphenolic compounds found in artichokes, both for their antioxidant activity and as health protectors. Some of the biological properties reported for artichokes are: hypocholesterolemic [1,3,4,8,10], anti-inflammatory [4,5,8,9], anticarcinogenic [8,11-14], antidyspeptic [15], antiseptic and antibiotic, among other health-benefiting activities [1,4,5,7-10,16-18]. It is also worth noting that extracts from the edible part of artichoke have a positive effect against cancer cell lines, decreasing their viability and/or cellular concentration, particularly in colon and breast cancer cells [12-14]. However, this same effect has not yet been studied in industrially produced vegetable discards.

In addition to this, artichokes, mainly in their "heart" fractions, contain inulin, which is a soluble fiber. This compound has applications in the nutraceutical and pharmaceutical industries due to its health-benefiting properties: digestibility, fat absorption, and water and mineral binding capacities $[2,4,19]$. The prebiotic activity of inulin has been vastly reported, with bifidogenic and lactobacillogenic effects even at low doses [13,20], amongst other activities $[2,21]$. Because of all the aforementioned properties, it would be interesting to study whether a process developed to recover antioxidants from artichoke discards (bracts) would also allow inulin to be recovered, and if so, to further examine the potential synergetic effect displayed in combination with phenolic compounds.

Previous studies have shown aqueous ethanolic solutions to be efficient in the extraction of polyphenols from artichokes, keeping their antioxidant capacity (AOC) active [12,13]. However, these studies were mainly developed using extracts from the edible fraction of the artichoke; either with different proportions of bracts, receptacles and stems, or from bracts obtained from fresh raw material. Therefore these conditions do not necessarily conform to those of the industrial processes where they are discarded. However, these characteristics do not usually match when the raw material is an industrial discard/byproduct. In addition to this, the aforementioned reports [12,13] do not evaluate the effect of some of the operational conditions of the extraction process on the antioxidant activity of the extract, nor do they evaluate the presence of inuline in the extract.

Consequently, this study aims to establish adequate operational conditions to obtain an extract from artichoke discards characterized in terms of phenolic compounds with AOC and inulin content. We also aim to study its effect on Caco-2 and MCF-7 cancer cell lines, to gain further knowledge about the alternative use of this agro-industrial discard and its subsequent valorization.

\section{Materials and Methods}

\subsection{Raw Material and Reagents}

Discarded outer bracts and, in a much lower proportion, stems of artichoke (Cynara scolymus L.), were provided by Penztke factory (San Felipe, Chile). Three batches of discards delivered by the company between September and November (spring) were used. The samples were frozen at $-20^{\circ} \mathrm{C}$. Afterwards, equal amounts of each batch were mixed, obtaining a single sample of artichoke discards, which was freeze-dried $\left(-53^{\circ} \mathrm{C}, 10 \mathrm{mTorr}\right)$, ground (particle size $<1.4 \mathrm{~mm}$ ) and finally vacuum-packed to be stored at room temperature until further use.

Artichoke discards were characterized by their proximal composition. Moisture, proteins, lipids, ashes fractions and non-nitrogen extracts were determined according to Association of Official Analytical Chemists (AOAC)(1990) methods. Total dietary fiber was measured using a commercial enzymatic kit (K-TDFR; Megazyme Ltd., Chicago, IL, USA) according to AOAC 991.43 and AOAC 985.29 (1990). 
Reagents such as Folin-Ciocalteu phenol reagent, $\mathrm{NaCO}_{3}, \mathrm{NaOH}, \mathrm{ZnSO}_{4}$ and Vanillin were obtained from Merck (Darmstadt, Germany). Fluorescein, AAPH (2,2-azobis (2 methylpropionamidine) dihydrochloride), phosphate buffered tablets, gallic acid and Trolox (6-hydroxy-2,5,7,8tetramethylchroman-2-carboxylic acid) were purchased from Sigma-Aldrich (St. Louis, MO, USA). Acetonitrile and formic acid were from Sigma-Aldrich (St. Louis, MO, USA). Ethanol and other solvents were obtained from Merck (Darmstadt, Germany). HPLC standards-chlorogenic acid (3-O-caffeoylquinic acid), neochlorogenic acid (5-O-caffeoylquinic acid), cynarin (1,3-di-O-caffeoylquinic acid) and the flavones luteolin ( $3^{\prime}, 4^{\prime}, 5,7$-tetrahydroxyflavone), apigenin (4' $, 5,7$-trihydroxyflavone) and apigenin-7-O-glucoside—were purchased from Sigma-Aldrich (St. Louis, MO, USA).

\subsection{Hydroalcoholic Extraction}

The extraction was performed in an orbital shaker at $200 \mathrm{rpm}$ using a 1:20 sample/solvent ratio and ethanol in concentrations of $25 \%, 50 \%, 75 \%$ and $100 \%$ as the extracting solvent. This process was performed at $30^{\circ} \mathrm{C}, 40{ }^{\circ} \mathrm{C}, 50^{\circ} \mathrm{C}$ and $60^{\circ} \mathrm{C}$ of temperature and $10,20,40$ and 60 min as extraction times. The resultant extracts were recovered by filtration and measured, and the presence of bioactive compounds was analyzed. After the best extraction conditions in this study were selected, the extract was used for the anti-proliferative evaluation. Then the ethanol in the extract was evaporated under vacuum and lyophilized.

\subsection{Bioactive Compound Determination}

Inulin content determination: Inulin content of the extracts was determined with the vanillin method proposed by Levine and Becker (1959) [22]. Briefly, a deproteinization of the sample was performed by mixing $1 \mathrm{~mL}$ of sample, $5 \mathrm{~mL}$ of Milli-Q water, $2 \mathrm{~mL}$ of $\mathrm{ZnSO}_{4} \cdot 10 \mathrm{H}_{2} \mathrm{O} 10 \%$, and $2 \mathrm{~mL}$ of $\mathrm{NaOH} 0.5 \mathrm{~N}$. The mixture was then filtrated and the volume quantified. In a test tube $2 \mathrm{~mL}$ of the filtrate, $0.8 \mathrm{~mL}$ of vanillin $1 \%$, and $2.2 \mathrm{~mL}$ of sulfuric acid were placed, shaken for $10 \mathrm{~s}$ and boiled for $2 \mathrm{~min}$, then cooled down in an ice bath for further $2 \mathrm{~min}$ and finally left to stand for $15 \mathrm{~min}$ at room temperature. Afterwards, absorbance was read at $520 \mathrm{~nm}$. A standard curve was created using the same procedure with commercial inulin $(10-70 \mu \mathrm{g} / \mathrm{mL})$ as control. The results are expressed as grams of inulin per $100 \mathrm{~g}$ of dried weight matter ( $\mathrm{g}$ Inulin/100 $\mathrm{g}$ dry weight $(\mathrm{dw})$ ).

Determination of total phenolic content (TPC): TPC was determined according to Soto et al. (2014) [14]. Briefly, $0.5 \mathrm{~mL}$ of sample was added to a test tube containing $3.75 \mathrm{~mL}$ of distilled water, $0.25 \mathrm{~mL}$ of Folin-Ciocalteu reagent $50 \%$ and $0.5 \mathrm{~mL}$ of sodium carbonate $10 \%$. After shaking, samples were left to stand at room temperature for 1-2 h until measured on a spectrophotometer at a $765 \mathrm{~nm}$ wavelength. The obtained absorbance was then interpolated in a calibration curve with gallic acid. The results are presented as milligram equivalents of gallic acid per $100 \mathrm{~g}$ of dry weight matter (mg GAE/100 g (dw)).

Determination of antioxidant capacity (AOC): The AOC of the extract was determined by the oxygen radical absorbance capacity (ORAC) technique. The protocol proposed by Garret et al. (2009) [23] was followed-200 $\mu \mathrm{L}$ of fluorescein (108 nM in phosphate buffered saline-PBS, pH 7.4) and $20 \mu \mathrm{L}$ of the extract were placed in a test tube. The samples were incubated at $37^{\circ} \mathrm{C}$ for $10 \mathrm{~min}$, and subsequently, $75 \mu \mathrm{L}$ of AAPH (79.7 mM in PBS buffer $\mathrm{pH} 7.4)$ was added to initiate the reactive oxygen species (ROS) generation. Fluorescence was then monitored for $60 \mathrm{~min}$, using 485/538 nm excitation/emission wavelengths. Results are based on the area displayed under the curve (AUC) as the fluorescence signal decrease, compared to the AUC of a curve made with Trolox as standard antioxidant. The results are expressed as $\mu \mathrm{mol}$ Trolox equivalents per $100 \mathrm{~g}$ of dry weight matter $(\mu \mathrm{molTE} / 100 \mathrm{~g}(\mathrm{dw}))$.

Polyphenol Characterization: The polyphenolic profile of the artichoke extracts was determined using HPLC equipment (Z220 HDm3; Agilent, Santa Clara, CA, USA) with diode array detector (DAD) and a Zorbax Eclipse XDB-C18 column $(4.6 \mathrm{~mm} \times 150 \mathrm{~mm}, 5 \mu \mathrm{m}$ particle size; Agilent, Santa Clara, CA, USA). The method followed was that proposed by Pandino et al. (2013) [24] with adaptations 
(for all the standards the limit of quantification used was $10 \mathrm{mg} / \mathrm{L}$ ); mobile phases were $\mathrm{A}: 98 \% \mathrm{H}_{2} \mathrm{O}$ with $2 \%$ formic acid, and B: $98 \%$ acetonitrile with $2 \%$ formic acid. A flow rate of $1 \mathrm{~mL} / \mathrm{min}$ was set throughout the gradient: $5 \%$ B for $5 \mathrm{~min}, 10 \%$ B for $10 \mathrm{~min}, 40 \%$ B for $15 \mathrm{~min}, 90 \%$ B for 5 min and back to $5 \% \mathrm{~B}$ for a further $5 \mathrm{~min}$. Apigenin-7-glucoside, Apigenin, Chlorogenic acid, Cynarin and Luteolin were used as standards. The reading wavelength throughout the analysis was $320 \mathrm{~nm}$.

\subsection{Carcinogenic Cell Lines Studies}

The effect of a selected extract of artichoke bracts on the viability of different cell lines was assessed according to Cobs-Rosas et al. (2015) [25]. Briefly, assays were performed on gingival fibroblasts (Inbiocriotec Ltda; Viña del Mar, Chili) as non-tumoral cell line, MCF-7 breast cancer cells (ATCC ${ }^{\circledR}$ HTB-22 ${ }^{\mathrm{TM}}$ ) and Caco-2 colorectal carcinoma epithelial cells (ATCC ${ }^{\circledR}$ HTB-37 ${ }^{\mathrm{TM}}$ ). These were grown in a culture flask containing Dulbecco's Modified Eagle's Medium (Corning ${ }^{\circledR}$ DMEM; Mediatech Inc, Manassas, VA, USA) supplemented with glutamine $2 \mathrm{mM}, 10 \%$ fetal bovine serum (FBS; Biological Industries, Connecticut, CT, USA) and penicillin $100 \mathrm{IU} / \mathrm{mL}$, streptomycin $10 \mu \mathrm{g} / \mathrm{mL}$ (Invitrogen ${ }^{\circledR}$; Thermo Fisher Scientific., Carlsbad, CA, USA) in an incubator (Forma ${ }^{\mathrm{TM}}$; Thermo Fisher Scientific, Waltham, MA, USA) with humidified environment and $5 \% \mathrm{CO}_{2}$, at $37{ }^{\circ} \mathrm{C}$. The culture media was replaced when required and trypsinized before the confluence. The cells were cultivated in a plate with 96 flat-bottom wells at a rate of $5 \times 10^{3}$ cells per well.

A lyophilized extract of artichoke discards was resuspended in the produced cell culture and filtrated through a $20 \mu \mathrm{m}$ filter. The cells were exposed to different concentrations of the extract for $24 \mathrm{~h}$. Subsequently, the media was removed and replaced with $200 \mu \mathrm{L}$ of a $4 \mathrm{mg} / \mathrm{L}$ resazurin solution and incubated in $5 \% \mathrm{CO}_{2}$ at $37^{\circ} \mathrm{C}$ for $4 \mathrm{~h}$. Fluorescence was measured at $544 / 590$ excitation/emission wavelengths (Appliskan plate reader; Thermo Fisher Scientific, Waltham, MA, USA). The resulting fluorescence detected is proportional to the number of viable cells present.

\subsection{Statistical Analysis}

The test used to analyze the relation between variables statistically-time and temperature of extraction and concentration of solvent with TPC and AOC obtained in the extracts-was the non-parametric Kruskal-Wallis test. Program $\mathrm{R}$ was the statistical platform; $p$-value $<0.05$ was considered statistically significant.

\section{Results}

\subsection{Proximal Characterization}

The raw sample had a moisture content of $86 \%$. Figure 1 shows the proximal analysis of a sample of lyophilized artichoke discards on a dry basis. It is worth noting the high amount of fiber found (52.91\%), with an insoluble/soluble dietary fiber ratio of 2.3-a value within FAO (Food and Agriculture Organization of the United Nations) and WHO (World Health Organization) recommendations. The sugar content of artichoke discards is about $16 \%$. Inulin content is about $7 \%$. 


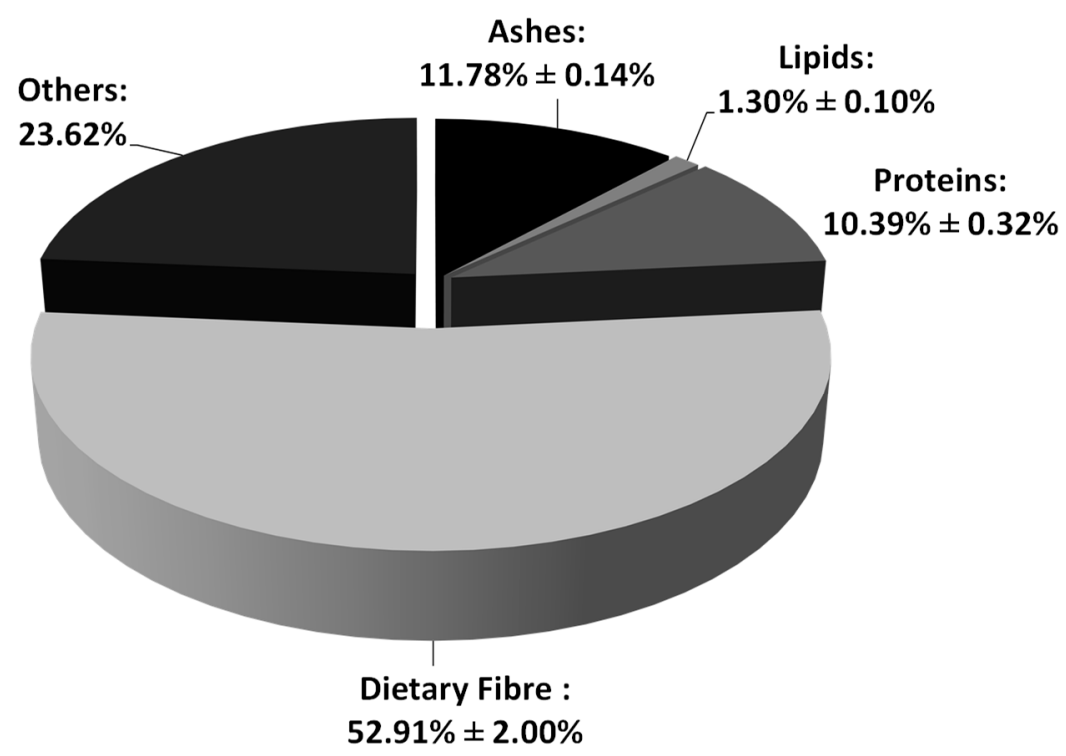

Figure 1. Proximal analysis of freeze-dried outer bracts of globe artichoke. Results expressed as (\%) on a dry basis. Mean \pm Standard Deviation (SD).

\subsection{Total Phenolic Content (TPC) and Antioxidant Capacity (AOC)}

Figures 2 and 3 show the results of TPC as mg GAE/100 $\mathrm{g}(\mathrm{dw})$ and AOC as $\mu \mathrm{mol}$ TE/100 $\mathrm{g}(\mathrm{dw})$, obtained using different ethanol concentrations, temperatures and times of extraction.
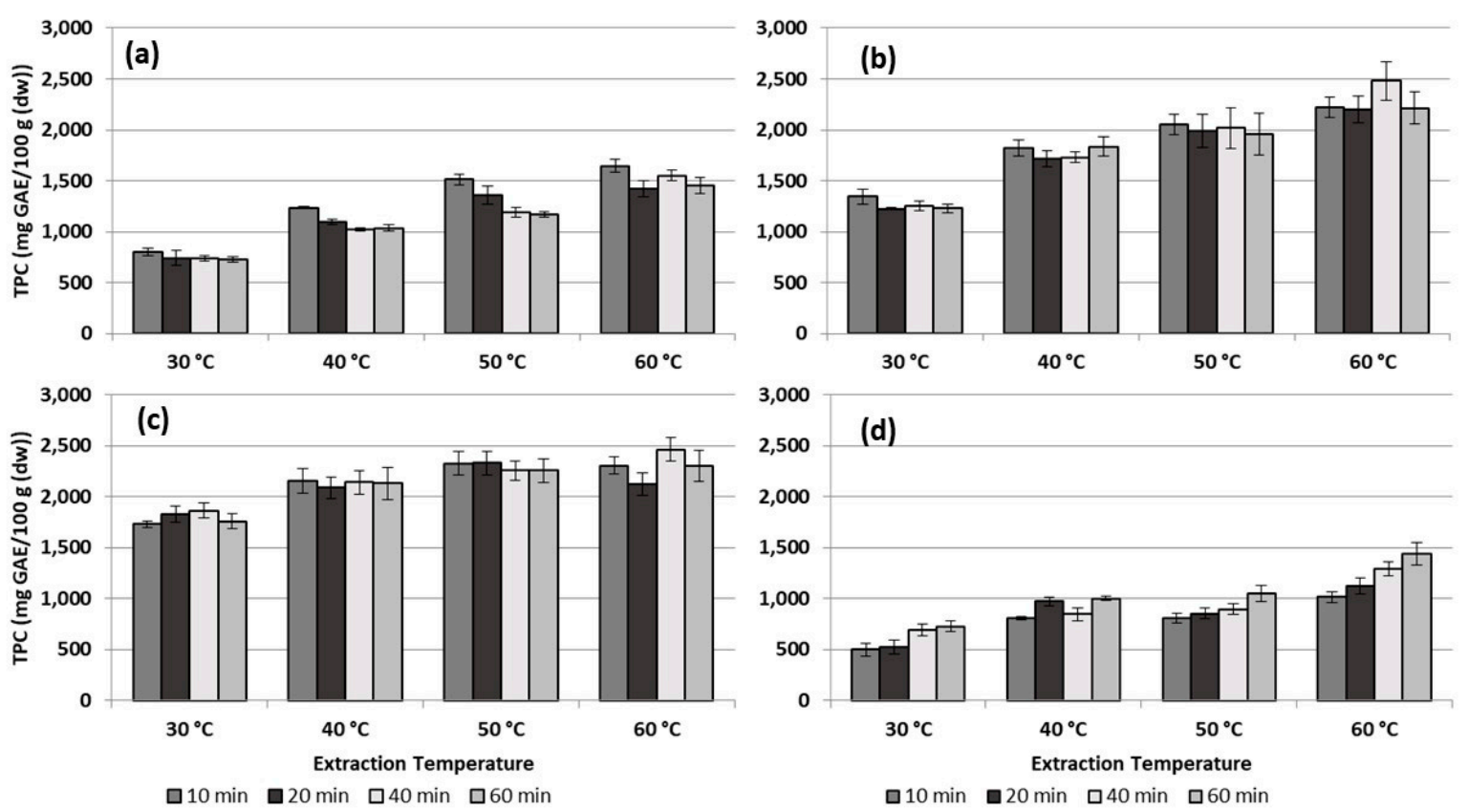

Figure 2. Effect of temperature, time of extraction and solvent composition (hydroalcoholic ethanol) on total phenolic content (TPC) of artichoke discards. GAE: Gallic acid equivalent. Solid/solvent ratio: 1/20; agitation: 200 rpm. Solvent: (a) 25\% ethanol; (b) 50\% ethanol; (c) 75\% ethanol; (d) 100\% ethanol. Mean \pm SD. 

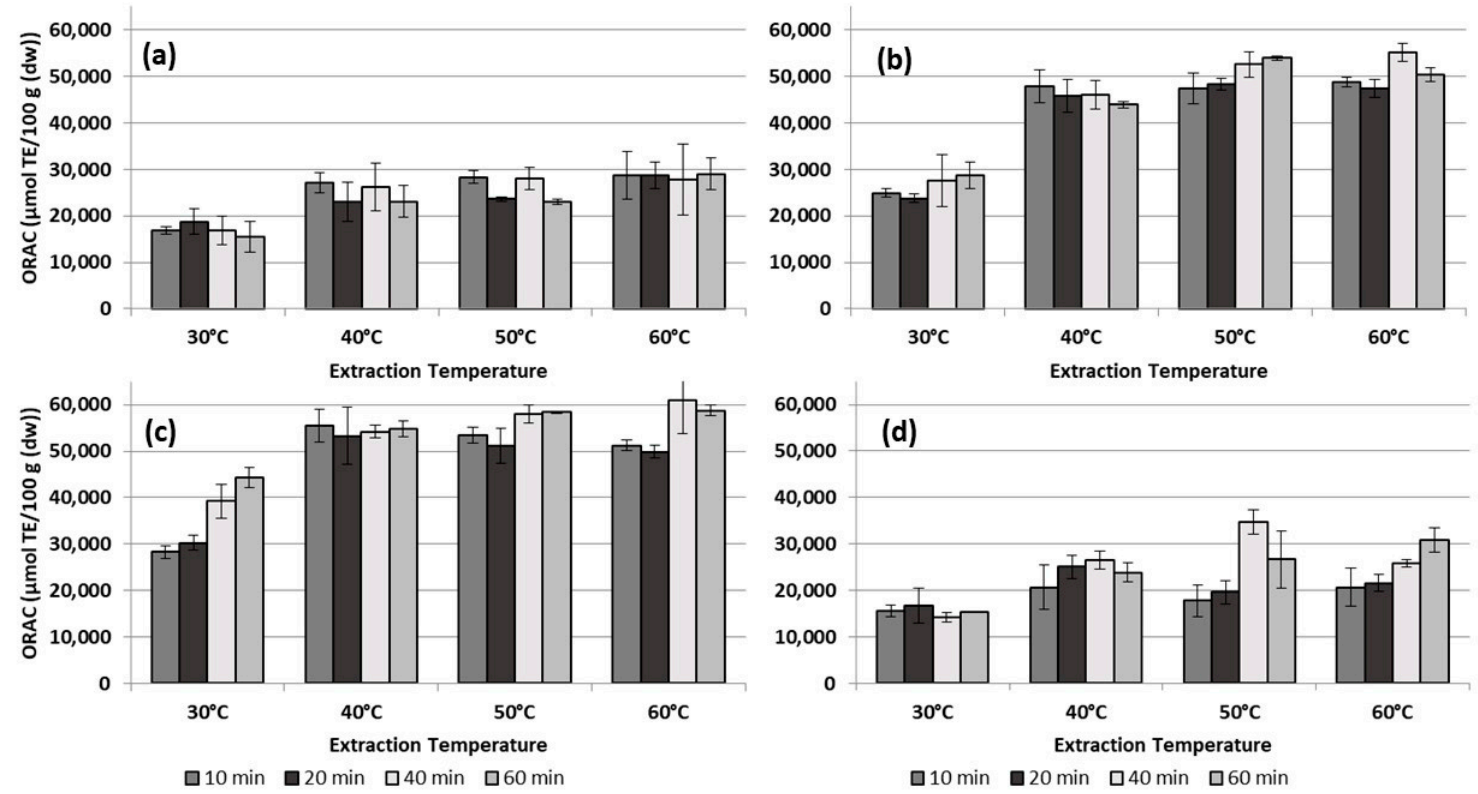

Figure 3. Effect of temperature, time of extraction and solvent composition (hydroalcoholic ethanol) on antioxidant activity (oxygen radical absorbance capacity (ORAC)) of artichoke discards. TE: Trolox equivalent. Solid/solvent ratio: 1/20; agitation: $200 \mathrm{rpm}$. Solvent: (a) 25\% ethanol; (b) 50\% ethanol; (c) $75 \%$ ethanol; (d) $100 \%$ ethanol. Mean \pm SD.

As shown in Figures 2 and 3, extraction conditions at concentrations of 75\% Ethanol (EtOH), regardless of time and temperature of extraction from $40{ }^{\circ} \mathrm{C}$ upwards, exhibited the highest levels of TPC and AOC in all the cases analyzed in this study. Values of $2461.89 \mathrm{mg}$ GAE/100 $\mathrm{g}(\mathrm{dw})$ and $61,014.67 \mu \mathrm{mol} \mathrm{TE} / 100 \mathrm{~g}(\mathrm{dw})$ were obtained for TPC and AOC, respectively, when $60{ }^{\circ} \mathrm{C}$ was the temperature applied during the extraction process. However, no significant differences ( $p$-value $>0.05$ ) were observed with the results obtained at $40{ }^{\circ} \mathrm{C}$. On the contrary, when using $25 \%$ or $100 \%$ ethanol, the worst results in terms of extraction of phenolic compounds and antioxidant activity were observed.

Regarding the effect of the extraction parameter, time of extraction is the variable with the lowest impact on the obtaining of phenolic compounds and AOC, in opposition to that reported by Zuorro et al. (2014) [12]. The concentration of solvent was by far the most conditioning parameter in this study, as can be observed in Table 1. The statistical analysis of results proved the strong relation between both TPC and AOC with the concentration of solvent $(p$-value $<0.05)$. The temperature of extraction was also related to TPC and AOC ( $p$-value $<0.05)$, affecting the latter variable more. On the other hand, as previously mentioned, time of extraction resulted in not being related to TPC nor to AOC ( $p$-value $>0.05)$.

Table 1. Kruskal-Wallis statistical analysis of the relation of the parameters studied: concentration of solvent, temperature and time of reaction with TPC and antioxidant capacity (AOC) results.

\begin{tabular}{cccc}
\hline & & $p$-Value & KW Chi \\
\hline \multirow{2}{*}{ TPC } & \% Ethanol & $2.23 \times 10^{-16}$ & 107.62 \\
& Temperature & $1.37 \times 10^{-2}$ & 10.66 \\
& Time & 0.96 & 0.32 \\
\hline \multirow{2}{*}{ AOC } & \% Ethanol & $2.21 \times 10^{-16}$ & 90.17 \\
& Temperature & $1.14 \times 10^{-4}$ & 20.86 \\
& Time & 0.78 & 1.01 \\
\hline
\end{tabular}


Thus, the highest influencing parameter is the concentration of solvent, followed by temperature. In contrast, time of extraction does not seem to be related to the extraction efficiency of TPC nor the AOC observed.

The selected parameters in terms of TPC and AOC obtained within our range of study were stated at $75 \%$ concentration of solvent, $10 \mathrm{~min}, 40{ }^{\circ} \mathrm{C}$-TPC: $2155.75 \mathrm{mg}$ GAE $/ 100 \mathrm{~g}(\mathrm{dw})$; AOC: $55,472.35 \mu \mathrm{mol}$ $\mathrm{TE} / 100 \mathrm{~g}(\mathrm{dw})$.

Figure 4 shows the correlation between TPC and AOC of the extracts obtained at all the conditions studied. TPC was measured by the Folin-Ciocalteu technique, which measures the TPC (phenolic rings) in a sample, whether these compounds display AOC or not. This technique may detect several interfering compounds, often leading to overestimated results [26,27]. However, as shown in Figure 4, we observe a clear correlation between TPC and AOC displayed in our extracts, in agreement with previous studies $[2,8,13,21,24,28,29]$, suggesting that the AOC displayed in the artichoke is due almost entirely to the phenolic compounds it presents. However, other authors could not prove or did not find a correlation between the phenolic content and the AOC displayed by this vegetable [30,31].

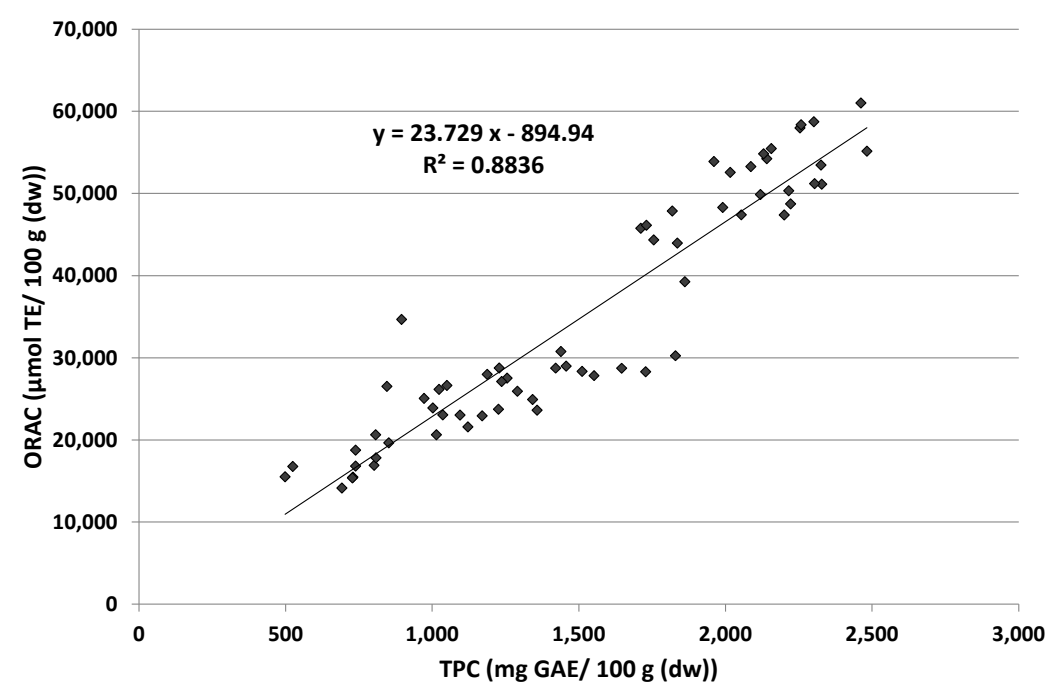

Figure 4. Correlated results for TPC and AOC (ORAC) at all the extraction conditions at the studied parameters: concentration of solvent, temperature and time of reaction.

\subsection{Artichoke Extract Characterization}

The hydroalcoholic extract obtained at best conditions studied-75:25 EtOH: $\mathrm{H}_{2} \mathrm{O}, 40{ }^{\circ} \mathrm{C}, 10 \mathrm{~min}$ of extraction-yielded a $12 \%(\mathrm{dw})$ of recovered solid. The polyphenolic profile of the extract characterized by HPLC is presented in Table 2, showing that phenolic compounds of artichoke discard extract are mainly mono- and dicaffeoylquinic acids, comprising more than $85 \%$ of all the total phenols present in the sample.

The most abundant polyphenol was identified as a dicaffeoylquinic acid, comprising almost half of the total phenolic compounds found in the extract (about $46 \%$ ). This compound is probably an isomer of cynarin (1,3 di-O-caffeoylquinic acid) such as 1,5 di-O-caffeoylquinic acid [2,32,33] or 3,5-di-O-caffeoylquinic acid [9,34]. Around $80 \%$ of the phenolic compounds identified are dicaffeoylquinic acid and chlorogenic acid (3-O-caffeoylquinic acid).

In a much lesser concentration (around 5\%) a flavone was detected. Apigenin-7-glucuronide is reported as one of the most representative flavonoids $[2,5,9,33,34]$ or even the most abundant polyphenol in Italian varieties of artichoke [32].

Together with phenolic compounds, the selected process in this study allows the recovery of inulin at $48.4 \%(\mathrm{dw})$ from the total inulin contained in the original raw material (artichoke discards). From the total artichoke discards, the solid fraction obtained corresponded to $12 \%$ in the extract, the fraction of inulin in this extract being $28.3 \%$. 
Table 2. Polyphenolic profile of artichoke extract obtained at $75: 25$ ethanol: water, $40{ }^{\circ} \mathrm{C}, 10 \mathrm{~min}$ of reaction.

\begin{tabular}{lc}
\hline & $\mathbf{A}_{\mathbf{x}} / \mathbf{A}_{\mathbf{T}} \mathbf{( \% )}$ \\
\hline Neo-Chlorogenic acid (5-O-Caffeoylquinic Acid) & $2.25 \pm 0.25$ \\
Chlorogenic Acid (3-O-Caffeoylquinic Acid) & $32.93 \pm 0.72$ \\
Dicaffeoylquinic Acid & $45.97 \pm 0.22$ \\
Flavone & $5.36 \pm 0.15$ \\
\hline Total 4 Main Compounds & 86.51 \\
\hline Total Area & 100 \\
\hline $\mathrm{A}_{\mathbf{x}}:$ Area of the chromatographic peak for compound $\mathrm{x} ; \mathrm{A}_{\mathrm{T}}:$ Total chromatographic area. Mean $\pm \mathrm{SD}$.
\end{tabular}

\subsection{Effect of Artichoke Extracts on the Viability of Cancer Cell Lines}

Figure 5 shows the effect of the artichoke extract on the viability of three cell lines, two of them being tumor cell lines. In order to do this, the selected extract previously obtained (extraction conditions: $75 \% \mathrm{EtOH}, 40{ }^{\circ} \mathrm{C}, 10 \mathrm{~min}$, concentrated and freeze-dried) was used in several concentrations. As shown in Figure 5, at low concentrations, a slight increase in terms of viability is produced in the three cell lines evaluated compared to control cells grown only in media. This was probably due to the presence of other compounds in the extract from natural raw material such as saccharides (inulin and others) that could exert a positive effect on the cell growth, especially on fibroblasts. However, by increasing the concentration of the extract, a drastic decrease in the viability of the carcinogenic lines (Caco-2 and MCF-7) was observed. When the cells are exposed to a concentration of extract of $750 \mathrm{mg} / \mathrm{L}$, maintenance of viability (100\%) of fibroblasts is observed, but in the case of MCF-7 breast cancer cells only $26.2 \%$ of cells were viable; similarly to what occurs with Caco- 2 colon cancer cells, with $47 \%$ of viable cells observed. Only by doubling the concentration of the extract to $1500 \mathrm{mg} / \mathrm{L}$ was it possible to observe a decrease in the viability of the fibroblasts, probably due to a pro-oxidant action of the extract. Despite the above, it was observed that viability of fibroblasts remained at $54.8 \%$ while Caco-2 and MCF-7 were viable in $30.4 \%$ and $19.3 \%$, respectively. The great difference between the effective minimum concentration of the extract over fibroblasts and carcinogenic cell lines would allow better control in the dosage of a medical supplement, if a potential pharmacological use of this extract was to be further studied.

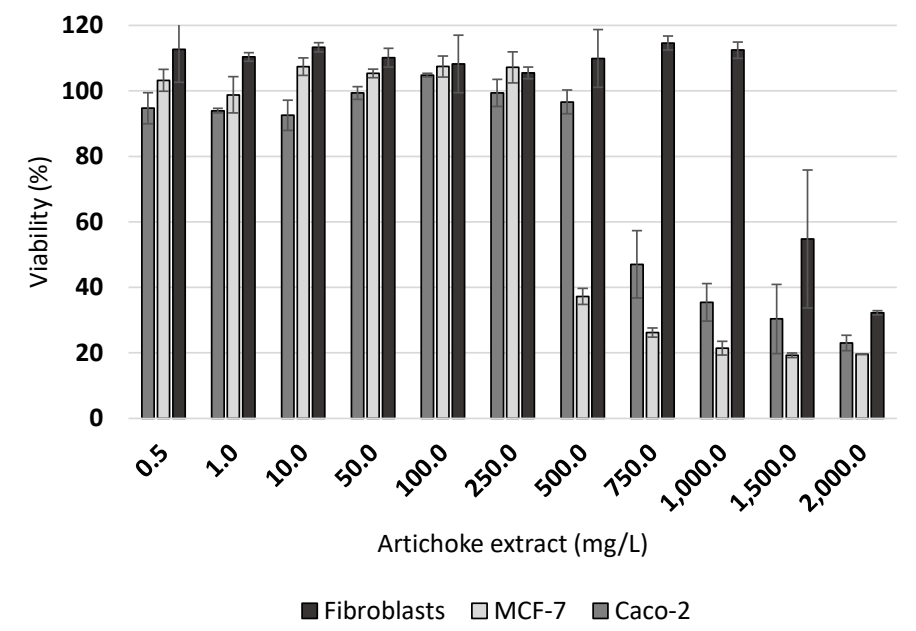

Figure 5. Anti-proliferative effect of artichoke discards extracts $\left(75 \% \mathrm{EtOH}, 40{ }^{\circ} \mathrm{C}, 10 \mathrm{~min}\right)$ on carcinogenic (MCF-7 and Caco-2) and normal (fibroblast) cell lines. The viability of control process (without the extract) for each cell line is considered 100\%. Mean \pm SD (standard deviation). 


\section{Discussion}

\subsection{Artichoke Discards Proximal Characterization}

The proximal composition of artichoke residues shows a significant content of mainly insoluble dietary fiber. This characteristic, and the low amount of fat observed (1.3\%), make these dried byproducts useful and valuable for industrial manufacture as low fat, high-fiber food ingredients with potential health benefits, reducing the risk of severe disorders, such as obesity, cardiovascular diseases, diabetes, colon-rectal cancer and others $[2,13,22]$. Even though the proximal characterization of artichoke discards has not been reported, when compared to those reported by Lutz et al. (2011) [31] of artichoke heads, we observe a greater presence of ashes and total carbohydrates (dietary fiber and others: $75.53 \%$ ) in agro-industrial discards. These differences may be due to the absence in our samples of the receptacle, which is very rich in soluble dietary fiber. Claus et al. (2015) [35], studying artichoke bracts, observed a different content of fiber than that presented in Figure 1, because only crude fiber may have been quantified, the value of which can approximate to the insoluble fiber content (mainly cellulose and lignin) of the materials under analysis. On the other hand, the highly recommended insoluble/soluble dietary fiber ratio presented a value of 2.3, which is much higher than that reported for artichoke heads (0.26: López et al., 1996 [36]).

Regarding inulin, Lattanzio et al. (2009) [4] stated the content of inulin in artichoke ranges from $19 \%$ to $34 \%(\mathrm{dw})$ and may represent up to $75 \%$ of the total glucosidic content. In any case, the percentage content of inulin varies according to the variety and parts of the plant studied and even the geographical locations and harvesting times [2,4]. Although Ruiz-Cano et al. (2014) [2] obtained the highest proportion of inulin in inner bracts (thermally treated), Ceccarelli et al. (2010) [1] reported flower heads to be particularly rich in this polysaccharide in European artichoke varieties. In contrast, this work was conducted on the most external parts of a South American (Chilean) variety.

The low content of inulin in artichoke industrial discards (7\%) compared to those reported by the mentioned authors is explained by the lack of receptacle, heart and/or inner bracts of artichoke, fractions which are industrially processed. This result is in agreement with that reported by López-Molina et al. (2005) [19] in artichoke discards, but lower compared to reports from other authors on the edible parts of the plant (heads of the Green Globe variety).

\subsection{Total Phenolic Content (TPC) and Antioxidant Capacity (AOC)}

The highest result obtained both for TPC and AOC—-2461.89 mg GAE/100 g (dw) and 61,014.67 $\mu \mathrm{mol}$ $\mathrm{TE} / 100 \mathrm{~g}(\mathrm{dw})$ respectively-was registered at $40 \mathrm{~min}$ and $60^{\circ} \mathrm{C}$ of temperature. Good recoveries were also obtained in milder conditions-2155.75 mg GAE/100 $\mathrm{g}(\mathrm{dw})$ and 55,472.35 $\mu \mathrm{mol} \mathrm{TE} / 100 \mathrm{~g}(\mathrm{dw})$ at $40^{\circ} \mathrm{C}$ and $10 \mathrm{~min}$ of reaction. These results are in line with those reported on European varieties of artichoke by Zuorro et al. (2014) [12]: 2414-3571 mg GAE/100 g in outer bracts and stems, and those by Curadi et al. (2005) [30], who reported 480-2980 mg GAE/100 g in the edible parts of the plant. On the other hand, Ninfali et al. (2005) [28] reported an AOC of $6552 \mu \mathrm{mol} \mathrm{TE} / 100 \mathrm{~g}$ (fresh weight (fw)), which would give a result higher than our values, considering the $86 \%$ moisture content in our raw material. For their part, Jiménez-Escrig et al. (2003) [37] reported values of $5040 \mathrm{mg}$ GAE/100 g in the edible parts of the plant, using more aggressive solvents and elaborated extraction protocols.

Regarding the phenolic content according to the part of the plant, some authors reported it to be higher in the heart and inner bracts of artichoke $[4,8,10,18,24]$, while others described the non-edible parts of the plant (outer bracts, leaves and stems) as being more enriched in polyphenolic compounds $[6,7,38,39]$. The variety of the vegetable and time of harvesting are also important factors to take into account $[1,5,10]$ when comparing results from previous studies, mainly conducted on Mediterranean varieties. All in all, the TPC and AOC values of this study were higher than expected for Green Globe American varieties [1]. Nevertheless, the wide range of factors determining the amount of phenolic compounds obtained (variety, time of harvesting, part of the plant studied, conditioning of raw sample, solvents and extraction techniques used) our results are consistent with those obtained 
from previous studies with similar characteristics $[2,4,8,12,28]$. Obtained results show the high content of antioxidants in the extracts from artichoke discards of this study, observing ORAC values much higher than those reported on products considered "superfruits" [40]. These results suggest the enormous potential application of these extracts as antioxidant ingredients and the benefits/suitability of utilizing industrial discards of artichokes.

Both for the recovery of phenolic compounds and the assessed antioxidant activity, it is possible to appreciate that the greatest effect of the operational conditions is related to the concentration of ethanol in the solution, followed by the temperature in the extraction process. In the first case, as expected, the values increased by increasing the concentration of ethanol, due to the polarity of the compounds present in the discards. It is important to remember that the dielectric constant of water and ethanol corresponds to 82 and 24, respectively, so mixtures of these solvents would allow both polar and non-polar compounds to be extracted. In addition to this, it was possible to determine that the pure solvent (ethanol) generated lower results than those obtained with hydroalcoholic mixtures, with the consequent joining and dragging effect of the phenolic compounds from the raw matter. These results contrast with studies by Zuorro et al. (2014) [12], who described the time of extraction as the most affecting parameter in the obtaining of TPC and AOC from outer bracts of artichoke with an aqueous ethanol solution, followed by temperature and sample weight (solvent volume ratio parameters). These differences may be explained by the Italian variety of artichoke studied by this author, in contrast with the South American used in this study. In addition to this, the blanching procedure $\left(85^{\circ} \mathrm{C}\right.$ in water, $\left.15 \mathrm{~min}\right)$ implemented by Zuorro et al. (2014) [12], could have contributed to the partial hydrolysis of the cell wall and subsequent release of polyphenols.

On the other hand, by increasing the process temperature between $30^{\circ} \mathrm{C}$ and $40{ }^{\circ} \mathrm{C}$ an increase in the values of TPC and AOC was observed, due to the higher solubility of the compounds in the extraction solutions. Nevertheless, when increasing the temperature above these values, no improvement in the extraction performance was observed. Temperatures above $40{ }^{\circ} \mathrm{C}$ proved efficient to release polyphenols from the plant tissue due to the matrix softening in the hydroalcoholic extract, as previously reported by Lutz et al. (2011) [31]. This process does not seem to happen at lower temperatures, such as $30^{\circ} \mathrm{C}$; hence the poor results of TPC and AOC registered at this temperature in all the concentrations of solvent and times of extraction studied. It is interesting to mention that artichokes possess endogenous enzymes that may affect the presence of phenolic compounds [2,4], which can be inactivated at high process temperatures, such as in the bleaching process, but which also affect the polyphenol stability. In some cases, the loss in the recovery of polyphenolic compounds after the bleaching treatment was reported up to $46 \%$ [30], while other authors reported that although some polyphenols were lost, some other types were observed [31].

\subsection{Artichoke Extract Characterization}

The polyphenol profile shows a high presence of caffeoylquinic and dicaffeoylquinic acids, which is in agreement with studies from previous authors $[1,2,4,9,21,33,37]$.

In the case of dicaffeoylquinic acid (45.97\%), however, this compound was not identified as cynarin specifically. Interestingly, the cynarin content in South American varieties of the artichoke is low, as previously reported by Silva da Costa et al. (2013) [3] and Noldin et al. (2003) [41] with Brazilian genotypes. In addition, the lack of blanching procedures could have affected the recovery of cynarin in its natural molecular structure, due to the potential presence of polyphenol oxidase enzyme, which is aggressive with ortho-dihydroxyphenolic compounds, as is the case with cynarin $[12,38]$. The chlorogenic acid (3-O-caffeoylquinic acid) identified represents a third of the TPC in the extract (around 33\%), which is in line with that reported by Schutz et al. (2004) [33] (33.3\%) in artichoke heads and slightly lower than that reported by Lattanzio et al. (2009) [4] (39\%). Chlorogenic acid was $113.34 \mu \mathrm{g} / \mathrm{mL}$, within the range of values described by Lombardo et al. (2010) [42] in outer bracts of Italian varieties, and in a higher concentration than that obtained by Garbetta et al. (2014) [9] using a 
methanolic solution in artichoke heads, although less than reported by Ceccarelli et al. (2010) [1], who also focused on the edible parts of Mediterranean varieties of the vegetable.

Finally, the low concentration of flavones and their derivatives found, compared to previous studies from other authors, support the already stated great diversity of the polyphenolic composition amongst the worldwide varieties of artichoke, different parts of the plant, harvesting times and different extraction procedures $[2,5,6,21,33,34,37,43]$.

Another attractive component in the extract is inulin, in a $28 \%(\mathrm{dw})$ concentration.

The multiple reports on the functional properties of inulin would enhance its use as an ingredient to improve digestive deficiencies. Moreover, the presence of inulin in the extract would promote a protective effect on antioxidant polyphenols [44].

It would, therefore, be interesting to study the synergic effects between inulin and phenolic antioxidants, which would enhance both their functional applications [45].

\subsection{Effect of Artichoke Extracts on the Viability of Cancer Cell Lines}

Low concentrations of extract produced an increase of the viability of three cell lines, probably due to the presence of other compounds that could exert a positive effect on the cell growth, especially on fibroblasts. However, by increasing the concentration of the extract, the carcinogenic lines (Caco-2 and MCF-7) decreased their proliferation. A higher potential resistance of the fibroblasts to the presence of the extract was observed, requiring at least twice the concentration than that for the tumor cells to decrease cell proliferation.

These results are in agreement with those reported by Mileo et al. (2012) [46]. They evaluated the anti-proliferative effect of an extract from the edible part of the artichoke on breast cancer cell lines, observing a dose-dependent effect on the cell line viability and growth, with no effect on healthy breast epithelial cells. However, the assays were conducted using extracts with concentrations up to $800 \mu \mathrm{M}$ (equivalent to $283.5 \mathrm{mg} / \mathrm{L}$ chlorogenic acid).

\section{Conclusions}

Agro-industrial byproducts of globe artichoke, Cynara scolymus L., are a great source of polyphenolic compounds. An extract rich in polyphenols, mainly mono- and dicaffeoylquinic acids, can be efficiently obtained from these discards through a mild procedure by using an ethanolic solution $(50-75 \%)$, moderate temperatures $\left(40{ }^{\circ} \mathrm{C}-60{ }^{\circ} \mathrm{C}\right)$ and short times of extraction $(10 \mathrm{~min})$. The concentration of solvent is the parameter with the greatest impact on the obtaining of polyphenols and AOC, followed by temperature. Inulin could also be retrieved from artichoke discards, although present at a naturally low concentration in the raw material. In addition to this, the extract has great anti-cancer potential effects on colon (Caco-2) and breast (MCF-7) cancer cells.

This study allowed the obtaining of an innovative extract with high content in bioactive compounds such as phenolic antioxidants and inulin, as well as a significant anti-proliferative effect on colon (Caco-2) and breast (MCF-7) cancer cells, which enhances its potential benefits for human health. These results promote the valorization of artichoke byproducts for further uses in different food or nutraceutical matrices, and even with pharmaceutical purposes. Since the developed technology is scalable, in subsequent studies the authors aim to study the production of a stabilized ingredient to be used in food matrixes and/or in nutraceutical formulations.

Author Contributions: Conceptualization, C.S.-M., L.P.-C. and M.E.Z.-H.; methodology, C.S.-M., D.N.-R., C.T.-A. and C.W.-O.; validation, D.N.-R., C.S.-M. and C.T.-A.; investigation, D.N.-R. and C.T.-A.; resources, L.P.-C., C.S.-M., C.W.-O. and M.E.Z.-H.; writing-original draft preparation, D.N.-R. and C.S.-M.; writing-review and editing, C.S.-M., D.N.-R., M.E.Z.-H., C.W.-O. and L.P.-C.; supervision, C.S.-M., L.P.-C. and M.E.Z.-H.; project administration, C.S.-M., L.P.-C. and M.E.Z.-H.; funding acquisition, C.S.-M., L.P.-C. and M.E.Z.-H. All authors have read and agreed to the published version of the manuscript.

Funding: This research was funding by Project R15F10006 (CONICYT) and BiValBi (Biotechnologies to Valorize the regional food Biodiversity in Latin America) Program FP7 IRSES 611493. 
Acknowledgments: The authors would like to thank CREAS GORE-CONICYT Project-R17A10001.

Conflicts of Interest: The authors declare no conflict of interest.

\section{References}

1. Ceccarelli, N.; Curadi, M.; Picciarelli, P.; Martelloni, L.; Sbrana, C.; Giovannetti, M. Globe artichoke as a functional food. Med. J. Nutrition Metab. 2010, 3, 197-201. [CrossRef]

2. Ruiz-Cano, D.; Pérez-Llamas, F.; Frutos, M.J.; Arnao, M.B.; Espinosa, C.; López-Jiménez, J.Á.; Castillo, J.; Zamora, S. Chemical and functional properties of the different by-products of artichoke (Cynara scolymus L.) from industrial canning processing. Food Chem. 2014, 160, 134-140. [CrossRef] [PubMed]

3. Silva de Costa, R.; Ferreira Ozela, E.; Ramos Barbosa, W.L.; Pereira, N.L.; Carrera Silva Junior, J.O. Physical Characterization, Chemistry and Physic-chemistry of Cynara Scolymus L. (Asteraceae) dry extract by spray-drying. Rev. Bras. Farmácia 2009, 90, 169-174.

4. Lattanzio, V.; Kroon, P.A.; Linsalata, V.; Cardinali, A. Globe artichoke: A functional food and source of nutraceutical ingredients. J. Funct. Foods 2009, 1, 131-144. [CrossRef]

5. Pandino, G.; Lombardo, S.; Williamson, G.; Mauromicale, G. Polyphenol profile and content in wild and cultivated Cynara cardunculus L. Ital. J. Agron. 2012, 7, 254-261. [CrossRef]

6. Negro, D.; Montesano, V.; Grieco, S.; Crupi, P.; Sarli, G.; De Lisi, A.; Sonnante, G. Polyphenol Compounds in Artichoke Plant Tissues and Varieties. J. Food Sci. 2012, 77, C244-C252. [CrossRef]

7. Gaafar, A.A.; Salama, Z.A. Phenolic Compounds from Artichoke (Cynara scolymus L.) By-products and their Antimicrobial Activities. J. Biol. Agric. Healthc. 2013, 3, 1-6.

8. Pereira, C.; Calhelha, R.C.; Barros, L.; Ferreira, I.C.F.R. Antioxidant properties, anti-hepatocellular carcinoma activity and hepatotoxicity of artichoke, milk thistle and borututu. Ind. Crops Prod. 2013, 49, 61-65. [CrossRef]

9. Garbetta, A.; Capotorto, I.; Cardinali, A.; D'Antuono, I.; Linsalata, V.; Pizzi, F.; Minervini, F. Antioxidant activity induced by main polyphenols present in edible artichoke heads: Influence of in vitro gastro-intestinal digestion. J. Funct. Foods 2014, 10, 456-464. [CrossRef]

10. Fratianni, F.; Pepe, R.; Nazzaro, F. Polyphenol Composition, Antioxidant, Antimicrobial and Quorum Quenching Activity of the "Carciofo di Montoro" (Cynara cardunculus var. scolymus) Global Artichoke of the Campania Region, Southern Italy. Food Nutr. Sci. 2014, 5, 2053-2062. [CrossRef]

11. Shukla, S.; Gupta, S. Apigenin: A promising molecule for cancer prevention. Pharm. Res. 2010, 27, $962-978$. [CrossRef] [PubMed]

12. Zuorro, A.; Maffei, G.; Lavecchia, R. Effect of solvent type and extraction conditions on the recovery of Phenolic compounds from artichoke waste. Chem. Eng. Trans. 2014, 39, 463-468. [CrossRef]

13. Mabeau, S.; Baty-Julien, C.; Hélias, A.B.; Chodosas, O.; Surbled, M.; Metra, P.; Durand, D.; Morice, G.; Chesné, C.; Mekideche, K. Antioxidant activity of artichoke extracts and by-products. Acta Hortic. 2007, 730, 491-496. [CrossRef]

14. Soto, C.; Caballero, E.; Pérez, E.; Zúñiga, M.E. Effect of extraction conditions on total phenolic content and antioxidant capacity of pretreated wild Peumus boldus leaves from Chile. Food Bioprod. Process. 2014, 92, 328-333. [CrossRef]

15. Marakis, G.; Walker, A.F.; Middleton, R.W.; Booth, J.C.L.; Wright, J.; Pike, D.J. Artichoke leaf extract reduces mild dyspepsia in an open study. Phytomedicine 2002, 9, 694-699. [CrossRef]

16. Schütz, K.; Muks, E.; Carle, R.; Schieber, A. Quantitative determination of phenolic compounds in artichoke-based dietary supplements and pharmaceuticals by high-performance liquid chromatography. J. Agric. Food Chem. 2006, 54, 8812-8817. [CrossRef]

17. Zhu, X.; Zhang, H.; Lo, R. Phenolic compounds from the leaf extract of artichoke (Cynara scolymus L.) and their antimicrobial activities. J. Agric. Food Chem. 2004, 52, 7272-7278. [CrossRef]

18. Kukić, J.; Popović, V.; Petrović, S.; Mucaji, P.; Ćirić, A.; Stojković, D.; Soković, M. Antioxidant and antimicrobial activity of Cynara cardunculus extracts. Food Chem. 2008, 107, 861-868. [CrossRef]

19. López-Molina, D.; Navarro-Martínez, M.D.; Melgarejo, F.R.; Hiner, A.N.P.; Chazarra, S.; Rodríguez-López, J.N. Molecular properties and prebiotic effect of inulin obtained from artichoke (Cynara scolymus L.). Phytochemistry 2005, 66, 1476-1484. [CrossRef]

20. Franck, A. Technological functionality of inulin and oligofructose. Br. J. Nutr. 2002, 87, S287-S291. [CrossRef] [PubMed] 
21. Pandino, G.; Lombardo, S.; Mauromicale, G.; Williamson, G. Profile of polyphenols and phenolic acids in bracts and receptacles of globe artichoke (Cynara cardunculus var. scolymus) germplasm. J. Food Compos. Anal. 2011, 24, 148-153. [CrossRef]

22. Levine, V.E.; Becker, W.W. The determination of inulin in blood and in urine by means of vanillin in acid medium. Clin. Chem. 1959, 5, 142-148. [CrossRef] [PubMed]

23. Garret, A.; Murray, B.; Robinson, R.; O'Neill, K. Measuring Antioxidant Capacity Using the ORAC and TOSC Assays. Methods Mol. Biol. 2010, 594, 251-262. [CrossRef]

24. Pandino, G.; Lombardo, S.; Mauromicale, G. Globe artichoke leaves and floral stems as a source of bioactive compounds. Ind. Crops Prod. 2013, 44, 44-49. [CrossRef]

25. Cobs-Rosas, M.; Concha-Olmos, J.; Weinstein-Oppenheimer, C.; Zúñiga-Hansen, M.E. Assessment of antiproliferative activity of pectic substances obtained by different extraction methods from rapeseed cake on cancer cell lines. Carbohydr. Polym. 2015, 117, 923-932. [CrossRef] [PubMed]

26. Prior, R.L.; Wu, X.; Schaich, K. Standardized methods for the determination of antioxidant capacity and phenolics in foods and dietary supplements. J. Agric. Food Chem. 2005, 53, 4290-4302. [CrossRef]

27. Ignat, I.; Volf, I.; Popa, V.I. A critical review of methods for characterisation of polyphenolic compounds in fruits and vegetables. Food Chem. 2011, 126, 1821-1835. [CrossRef]

28. Ninfali, P.; Mea, G.; Giorgini, S.; Rocchi, M.; Bacchiocca, M. Antioxidant capacity of vegetables, spices and dressings relevant to nutrition. Br. J. Nutr. 2005, 93, 257-266. [CrossRef]

29. El Sohaimy, S.A. Chemical composition, antioxidant and antimicrobial potential of artichoke. Open Nutraceuticals J. 2014, 7, 15-20. [CrossRef]

30. Curadi, M.; Picciarelli, P.; Lorenzi, R.; Graifenberg, A.; Ceccarelli, N. Antioxidant activity and phenolic compounds in the edible parts of early and late italian artichoke (Cynara scolymus L.) varieties. Ital. J. Food Sci. 2005, 17, 33-44.

31. Lutz, M.; Henríquez, C.; Escobar, M. Chemical composition and antioxidant properties of mature and baby artichokes (Cynara scolymus L.), raw and cooked. J. Food Compos. Anal. 2011, 24, 49-54. [CrossRef]

32. Pandino, G.; Courts, F.L.; Lombardo, S.; Mauromicale, G.; Williamson, G. Caffeoylquinic acids and flavonoids in the immature Inflorescence of globe artichoke, wild cardoon, and cultivated cardoon. J. Agric. Food Chem. 2010, 58, 1026-1031. [CrossRef] [PubMed]

33. Schütz, K.; Kammerer, D.; Carle, R.; Schieber, A. Identification and quantification of caffeoylquinic acids and flavonoids from artichoke (Cynara scolymus L.) heads, juice, and pomace by HPLC-DAD-ESI/MSn. J. Agric. Food Chem. 2004, 52, 4090-4096. [CrossRef]

34. Lombardo, S.; Pandino, G.; Mauro, R.; Mauromicale, G. Variation of phenolic content in globe artichoke in relation to biological, technical and environmental factors. Ital. J. Agron. 2009, 4, 181-189. [CrossRef]

35. Claus, T.; Maruyama, S.A.; Palombini, S.V.; Montanher, P.F.; Bonafé, E.G.; de Oliveira Santos Junior, O.; Matsushita, M.; Visentainer, J.V. Chemical characterization and use of artichoke parts for protection from oxidative stress in canola oil. LWT-Food Sci. Technol. 2015, 61, 346-351. [CrossRef]

36. López, G.; Ros, G.; Rincón, F.; Periago, M.J.; Martínez, M.C.; Ortuño, J. Relationship between Physical and Hydration Properties of Soluble and Insoluble Fiber of Artichoke. J. Agric. Food Chem. 1996, 44, 2773-2778. [CrossRef]

37. Jiménez-Escrig, A.; Dragsted, L.O.; Daneshvar, B.; Pulido, R.; Saura-Calixto, F. In vitro antioxidant activities of edible artichoke (Cynara scolymus L.) and effect on biomarkers of antioxidants in rats. J. Agric. Food Chem. 2003, 51, 5540-5545. [CrossRef]

38. Zuorro, A.; Maffei, G.; Lavecchia, R. Reuse potential of artichoke (Cynara scolymus L.) waste for the recovery of phenolic compounds and bioenergy. J. Clean. Prod. 2016, 111, 279-284. [CrossRef]

39. Romani, A.; Pinelli, P.; Cantini, C.; Cimato, A.; Heimler, D. Characterization of Violetto di Toscana, a typical Italian variety of artichoke (Cynara scolymus L.). Food Chem. 2006, 95, 221-225. [CrossRef]

40. Chang, S.K.; Alasalvar, C.; Shahidi, F. Superfruits: Phytochemicals, antioxidant efficacies, and health effects-A comprehensive review. Crit. Rev. Food Sci. Nutr. 2019, 59, 1580-1604. [CrossRef]

41. Noldin, V.F.; Cechinel Filho, V.; Delle Monache, F.; Benassi, J.C.; Christmann, I.L.; Pedrosa, R.C.; Yunes, R.A. Chemical Composition and Biological Activities of the Leaves of Cynara scolymus L. (Artichoke). Cultivated in Brazil. Quim. Nova 2003, 26, 331-334. [CrossRef] 
42. Lombardo, S.; Pandino, G.; Mauromicale, G.; Knödler, M.; Carle, R.; Schieber, A. Influence of genotype, harvest time and plant part on polyphenolic composition of globe artichoke [Cynara cardunculus L. var. scolymus (L.) Fiori]. Food Chem. 2010, 119, 1175-1181. [CrossRef]

43. Sánchez-Rabaneda, F.; Jauregui, O.; Lamuela-Raventos, R.M.; Bastida, J.; Viladomat, F.; Codina, C. Identification of phenolic compounds in artichoke waste by high- performance liquid chromatography-Tandem mass spectrometry. J. Chromatogr. A 2003, 1008, 57-72.

44. Michalska, A.; Wojdyło, A.; Brzezowska, J.; Majerska, J.; Ciska, E. The influence of inulin on the retention of polyphenolic compounds during the drying of blackcurrant juice. Molecules 2019, 24, 4167. [CrossRef] [PubMed]

45. Giammona, G.; Mauro, N.; Scialabba, C. Inulin for Cancer Therapy: Present and Perspectives. Int. J. Pharma Res. Rev. 2016, 5, 63-69.

46. Mileo, A.M.; Di Venere, D.; Linsalata, V.; Fraioli, R.; Miccadei, S. Artichoke polyphenols induce apoptosis and decrease the invasive potential of the human breast cancer cell line MDA-MB231. J. Cell. Physiol. 2012, 227, 3301-3309. [CrossRef]

(C) 2020 by the authors. Licensee MDPI, Basel, Switzerland. This article is an open access article distributed under the terms and conditions of the Creative Commons Attribution (CC BY) license (http://creativecommons.org/licenses/by/4.0/). 